\title{
Autoantibodies in chronic arthritis of childhood: relations with each other and with histocompatibility antigens
}

Peter N Malleson, Marinda Y Fung, Ross E Petty, Murray J Mackinnon, Maria-Louise Schroeder

\begin{abstract}
Background Studies have shown the presence of either antibodies to histone or anticardiolipin antibodies in some forms of childhood chronic arthritis. The relation between these autoantibodies has not been previously reported, however, and the immunogenetics of their association with childhood arthritis has not been studied.

Methods The interrelation of fluorescent antinuclear antibodies, antibodies to histone, and anticardiolipin antibodies and their associations with histocompatibility antigens (HLA) were studied in 114 children with chronic arthritis (45 children with pauciarticular onset juvenile chronic arthritis (JCA), 22 with polyarticular onset JCA, 13 with systemic onset JCA, and 34 with juvenile psoriatic arthritis (JPsA). Antibodies to histone and anticardiolipin antibodies were determined in 108 children. HLA antigens $(A, B, C$, and DR) were studied in the 83 white children.
\end{abstract}

Results Antibodies to histone occurred in $0 \%$ (systemic onset JCA) to $42 \%$ (uveitis negative, pauciarticular onset JCA), and anticardiolipin antibodies in $26 \%$ (JPsA) to $55 \%$ (polyarticular onset JCA) of patients. Only 12 patients $(11 \%)$ had both antibodies to histone and anticardiolipin antibodies. Neither antibodies to histone nor anticardiolipin antibodies associated with the type of arthritis. Neither of these antibodies alone associated with uveitis. Antibodies to histone were associated with HLA-A2, probably reflecting the known association of HLA-A2 with pauciarticular onset JCA. There was no other HLA association. Fluorescent antinuclear antibodies occurred most often in patients with uveitis; however, the occurrence of fluorescent antinuclear antibodies in patients with pauciarticular onset JCA (the group most at risk for uveitis) was not significantly greater in children with uveitis than in those without uveitis (100 and $88 \%$ respectively).

Conclusions Although antibodies to histone and anticardiolipin antibodies often occur in serum samples from patients with JCA and JPsA, they rarely occur together. Their presence does not associate with uveitis. This study did not show any strong evidence that production of either antibodies to histone or anticardiolipin antibodies in patients with JCA or JPsA is under the control of the histocompatibility locus.

\section{(Ann Rheum Dis 1992; 51: 1301-1306)}

The most consistent laboratory findings in children with juvenile chronic arthritis (JCA) are the presence of a limited range of autoantibodies $^{1}$ and the association of certain antigens of the major histocompatibility complex with subsets of disease. ${ }^{2-4}$ Antibodies to nuclear antigens (reviewed by Lang and Shore ${ }^{1}$, and to cardiolipin ${ }^{5}$ are the most commonly identified autoantibodies in serum samples from children with JCA. Although the antigenic specificities of the antinuclear antibodies are largely unknown, some studies have identified antibodies to histone in a considerable number of patients. . $^{70}$ The association of HLA-B27 with the seronegative spondyloarthropathies, ${ }^{2}$ of DR5 and DR8 with early onset pauciarticular JCA,${ }^{3}$ and of HLA-DR4 with rheumatoid factor positive polyarticular onset $\mathrm{JCA}^{4}$ are well recognised.

Associations between specific autoantibodies and HLA antigens have been reported in a number of rheumatic diseases. HLA-DR4 has been shown to be associated with the presence of IgM rheumatoid factor in patients with rheumatoid arthritis. ${ }^{11}$ An association of HLADR3 with antibodies to Ro and La in patients with systemic lupus erythematosus (SLE) has been shown. ${ }^{12}$ Antibodies to Ro have been associated with HLA-DQ1/DQ2 heterozygosity, and antibodies to $\mathrm{Sm}$ with HLA-DR4 in patients with SLE. ${ }^{13}$ In a study of patients with scleroderma ${ }^{14}$ antibodies to topoisomerase I were associated with HLA-DR5, and antibodies to Pm-Scl with HLA-DR3. It has been suggested that the clinical heterogeneity of SLE and scleroderma can be explained, at least in part, by genetic differences (as shown by HLA associations) influencing the production of particular autoantibodies which in complex ways cause different disease manifestations. ${ }^{13} 14$

IgM rheumatoid factor has been associated with HLA-DR4 in polyarticular onset $\mathrm{JCA}^{15}$ and associations have been noted between antinuclear antibodies shown by immunofluorescence and HLA-DR5 $5^{16}$ and DR8 $8^{16-18}$ in children with JCA. Whether antibodies to histone and anticardiolipin antibodies occur together in the same patient, and whether or not there are HLA associations with the production of these antibodies has not previously been addressed. This study was undertaken to examine associations between antibodies to histone, anticardiolipin antibodies, and HLA antigens in children with JCA or juvenile psoriatic arthritis (JPsA).

Patients and methods

PATIENTS

One hundred and fourteen children were studied.
Accepted for publication 15 July 1992 
All were followed at the rheumatology clinics of British Columbia's Children's Hospital and the Vancouver Arthritis Centre of the Arthritis Society (British Columbia and Yukon division). Eighty patients fulfilled both the American College of Rheumatology criteria for JRA ${ }^{19}$ and the European League Against Rheumatism criteria for the diagnosis of JCA. ${ }^{20}$ The term JCA will be used throughout this paper. Forty five children (40 girls), 21 of whom had chronic anterior uveitis, had pauciarticular onset JCA, 22 (20 girls) had polyarticular onset JCA, and 13 (three girls) systemic onset JCA. Thirty four children ( 24 girls) had definite JPsA as defined by Southwood et al. ${ }^{21}$ Seven of these had chronic anterior uveitis. Uveitis was detected by slit lamp examinations performed at approximately four month intervals. Active uveitis was defined as the presence of cells and flare in the anterior chamber.

\section{FLUORESCENT ANTINUCLEAR ANTIBODIES}

Fluorescent antinuclear antibodies of $\operatorname{IgG}, \operatorname{IgA}$, and $\operatorname{IgM}$ isotypes were detected by a standard indirect immunofluorescence test using $\mathrm{HEp}-2$ cells (Kallestad Laboratories) as substrate, a single fluorescein conjugated burro antiserum to human immunoglobulins (Kallestad) and patient serum samples at a screening dilution of $1: 20 .^{22}$ Positive serum samples were titrated to their endpoint. Normal serum (negative control) and serum samples from a child with SLE (positive control) were analysed simultaneously.

\section{ANTIBODIES TO HISTONE}

IgG antibodies to histone were determined by immunoblotting against extracts of $\mathrm{HEp}-2$ cell nuclei at a serum dilution of $1: 100$ as described previously. ${ }^{7}$ In brief, a nuclear pellet was prepared from HEp-2 cells (American Type Culture Collection) using a modification of the method of Lerner and Steitz. ${ }^{23}$ The proteins were separated on the basis of molecular weight by sodium dodecyl sulphate polyacrylamide gel electrophoresis ${ }^{24}$ and were transferred electrophoretically to nitrocellulose membranes. ${ }^{25}$ The nitrocellulose blots were then incubated with control or test serum samples (1/100 dilution) and bound immunoglobulins were visualised with alkaline phosphatase conjugated goat antihuman IgG. A doublet of 33/35 kilodaltons was considered to be histone $\mathrm{Hl}$ as we have shown previously ${ }^{7}$ that antibodies recognising this doublet also recognise $\mathrm{Hl}$ when histones are prepared from HEp-2 cells using the method of Candido and Dixon for histone isolation, ${ }^{26}$ and a commercial histone preparation (Sigma). For the purpose of this study antibodies to histone were only considered to be present if antibodies to $\mathrm{Hl}$ were present. A few serum samples also contained antibodies to other proteins (probably core histones), but because of the small numbers we did not analyse these separately.

ANTICARDIOLIPIN ANTIBODIES

IgG antibodies to cardiolipin were detected by an enzyme linked immunosorbent assay (ELISA). In brief, the serum samples diluted $1 / 100$ in phosphate buffered saline containing $0.1 \%$ gelatin, $0.5 \%$ bovine gammaglobulin, $0.1 \%$ bovine serum albumin, and $0.001 \mathrm{M}$ EDTA were applied to the wells on polypropylene plates coated with cardiolipin (Sigma) at a concentration of $5 \mu \mathrm{g} / \mathrm{ml}$ in ethanol and blocked with $0 \cdot 1 \%$ bovine serum albumin. A laboratory standard was prepared from a patient with high levels of anticardiolipin antibodies using reference serum samples from the Lupus Research Laboratory, St Thomas's Hospital, London (paper presented at the World Symposium on Antiphospholipid Antibodies, St Thomas's Hospital, London, 4 April 1986). For each assay a standard curve was obtained using dilutions of the laboratory standard. A known negative control was run on each plate and between 15 and 20 normal serum samples from blood donors (from the 49 used to obtain the normal range and mean) were run in parallel. A serum sample was considered positive for anticardiolipin antibodies if the reading obtained was greater than 31.9 IgG phospholipid units (i.e. greater than three standard deviations above the mean of 14.5 for 49 local blood donors)

Most of these tests were performed in each patient on the same serum sample. As a result of inadequate volumes a few patients had tests performed on different serum samples.

\section{RHEUMATOID FACTOR}

IgM rheumatoid factor was determined using a commercial latex agglutination slide test. A test was considered positive if agglutination occurred at a dilution of 1/20.

\section{HISTOCOMPATIBILITY ANTIGENS}

HLA typing for class I $(\mathrm{A}, \mathrm{B}, \mathrm{C})$ and class II (DR) antigens was performed using a standard microcytotoxicity test ${ }^{27}$ in 83 white children.

\section{STATISTICAL ANALYSES}

The rates of positive test results between disease groups were compared using Fisher's two tailed exact test. The levels of anticardiolipin antibodies were compared using one way analysis of variance. All calculations were performed with the PROC, FREQ, and PROC GLM programs of the SAS/STAT personal computer package.

\section{Results}

Table 1 gives the occurrence of fluorescent antinuclear antibodies, antibodies to histone, and anticardiolipin antibodies as well as the mean titres of anticardiolipin antibodies for children with JCA of each onset type, with or without uveitis, and for children with JPsA. As a result of the limited availability of serum samples not all tests were performed on each sample.

Fluorescent antinuclear antibodies were present less often in children with JPsA than in all the children with JCA $(p=0.01)$. As expected, 
Table 1 Fluorescent antinuclear antibodies, antibodies to histone, and anticardiolipin antibodies in serum samples from 114 children with juvenile chronic arthritis (FCA)

\begin{tabular}{lllll}
\hline Diagnosis & $\begin{array}{l}\text { Positive fluorescent } \\
\text { antinuclear } \\
\text { antibodies (\%) }\end{array}$ & $\begin{array}{l}\text { Positive for } \\
\text { antibodies to } \\
\text { histone antibodies (\%) }\end{array}$ & $\begin{array}{l}\text { Positive for } \\
\text { anticardiolipin } \\
\text { antibodies (\%) }\end{array}$ & $\begin{array}{l}\text { Mean }(S E) \\
\text { anticardiolipin } \\
\text { antibodies }\end{array}$ \\
\hline Pauciarticular onset JCA & $42 / 45(93)$ & $14 / 45(31)$ & $18 / 42(43)$ & $27 \cdot 8(2 \cdot 45)$ \\
$\quad$ Uveitis positive & $21 / 21(100)$ & $4 / 21(19)$ & $7 / 19(37)$ & $26 \cdot 7(4 \cdot 02)$ \\
$\quad$ Uveitis negative & $21 / 24(88)$ & $10 / 24(42)$ & $11 / 23(48)$ & $28 \cdot 6(3 \cdot 08)$ \\
Polyarticular onset JCA & $17 / 21(81)$ & $4 / 22(18)$ & $11 / 20(55)$ & $34 \cdot 4(3 \cdot 30)$ \\
Systemic onset JCA & $4 / 13(31)$ & $0 / 13(0)$ & $4 / 12(33)$ & $28 \cdot 8(4 \cdot 62)$ \\
JPsA & $19 / 34(56)$ & $4 / 34(12)$ & $9 / 34(26)$ & $28 \cdot 8(4 \cdot 85)$ \\
Uveitis positive & $6 / 7(86)$ & $2 / 7(29)$ & $2 / 7(29)$ & $45 \cdot 7(17 \cdot 7)$ \\
Uveitis negative & $13 / 27(48)$ & $2 / 27(7)$ & $7 / 27(26)$ & $24 \cdot 8(4 \cdot 22)$ \\
\hline
\end{tabular}

fluorescent antinuclear antibodies were found most often in children with pauciarticular onset JCA and least often in those with systemic onset JCA. The presence of fluorescent antinuclear antibodies was associated with uveitis in the whole JCA group, occurring in 21 of 21 patients with uveitis compared with 42 of 58 children without uveitis $(\mathrm{p}=0.005)$. A similar trend was noted in patients with JPsA in whom six of seven $(86 \%)$ of those with uveitis were positive for fluorescent antinuclear antibodies compared with 13 of $27(48 \%)$ of those without uveitis $(p=0 \cdot 1)$. Although all patients with pauciarticular onset JCA and uveitis were positive for fluorescent antinuclear antibodies, however, so were $88 \%$ of patients with pauciarticular onset JCA who did not have uveitis $(p=0 \cdot 2)$. Fluorescent antinuclear antibodies occurred significantly less often in patients with JPsA without uveitis (48\%) than in patients with pauciarticular onset JCA without uveitis $(88 \%)(p=0.003)$. Of the 77 serum samples titrated to their endpoint, titres were $1 / 20$ in $5 \%, 1 / 40$ in $18 \%, 1 / 80$ in $27 \%, 1 / 160$ in $29 \%, 1 / 320$ in $16 \%, 1 / 640$ in $4 \%$, and $1 / 1280$ or higher in $1 \%$. Exclusion of the $1 / 20$ serum samples in patients with pauciarticular onset JCA or JPsA and uveitis made no difference to the comparisons.

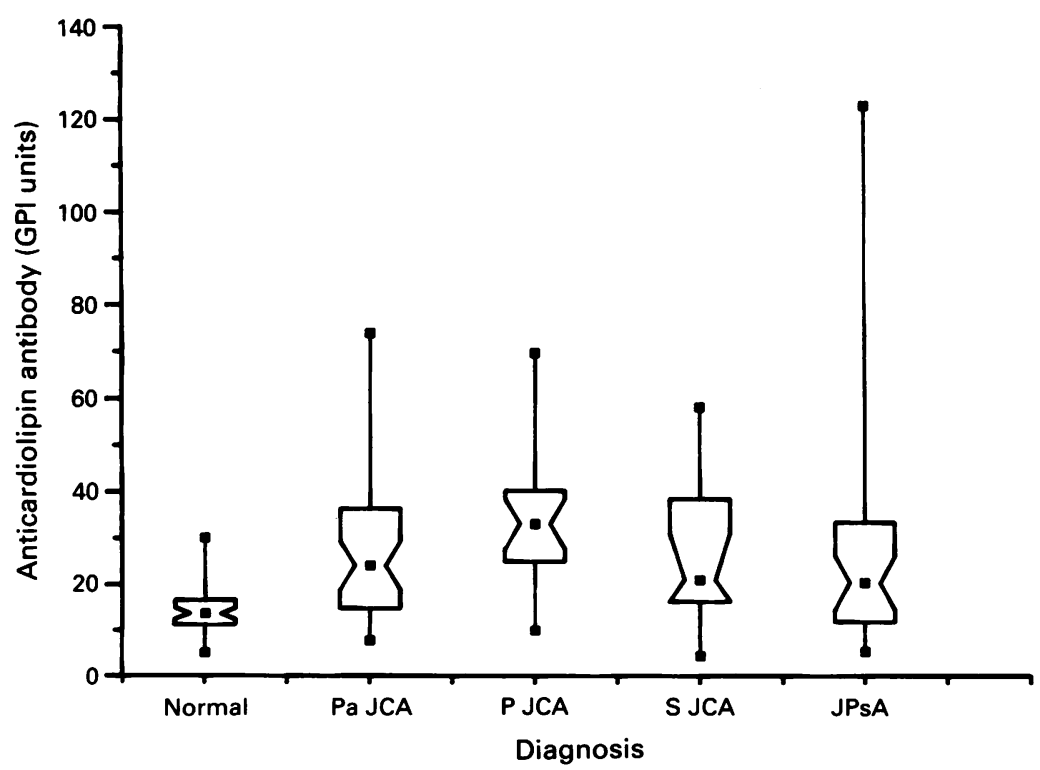

Box plot of anticardiolipin antibody levels in 108 children with chronic arthritis compared with 49 blood donor controls. The notch is the median value. The upper and lower edges of the box define the 75th and 25th centiles respectively. The upper and lower points define the maximum and minimum values respectively. $\mathrm{Pa} F C A=$ pauciarticular onset juvenile chronic arthritis; $P \mathcal{F C A}=$ polyarticular onset juvenile chronic arthritis; $S \mathcal{F C A}=$ systemic onset arthritis; $P \mathcal{F C A}=$ polyarticular onset juvenile chronic arthritis;
juvenile chronic arthritis; $\mathcal{F} P s A=$ juvenile psoriatic arthritis.
The occurrence of antibodies to histone differed significantly between different patient groups $(p=0.04)$ (see table 1 ), occurring most often in patients with pauciarticular onset JCA without uveitis, and being undetectable in serum samples from patients with systemic onset JCA. There was no evidence of a difference in the occurrence of antibodies to histone between patients with JCA or JPsA $(p=0 \cdot 2)$, or between patients with or without uveitis in either the pauciarticular onset JCA or JPsA patient groups. Antibodies to histone were found significantly more often in the pauciarticular onset JCA group without uveitis than in the patients with JPsA without uveitis $(p=0.004)$. As might be expected, almost all the children positive for antibodies to histone were positive for fluorescent antinuclear antibodies (20 of 22), but most of the patients positive for fluorescent antinuclear antibodies were negative for antibodies to histone (62 of 82), indicating that the fluorescent antinuclear antibodies of JCA and JPsA include, but are not limited to, histone $\mathrm{H} 1$.

Levels of anticardiolipin antibodies were significantly higher in the patients than in controls $(p=0.0001)$ (see figure). Although anticardiolipin antibodies were found in $26-55 \%$ of patients in all subgroups, neither the occurrence of anticardiolipin antibody positivity nor the mean level of anticardiolipin antibodies differed significantly between patient groups. There was no evidence of a difference in mean levels of anticardiolipin antibodies between patients positive and negative for fluorescent antinuclear antibodies $(p=0 \cdot 4)$. There was no evidence of a difference in levels of anticardiolipin antibodies between children with or without uveitis, either in patients with pauciarticular onset JCA or with JPsA.

The occurrence of antibodies to histone and anticardiolipin antibodies in the same patient, though rare, was more common in the patients with JPsA with uveitis (two of seven), than in the patients with JPsA without uveitis (none of 27) $(p=0.04)$ (table 2). As most of the patients with JPsA with uveitis (five of seven) did not have both antibodies, however, and as no association was found between the presence of the two antibodies and uveitis in the pauciarticular onset JCA group, this finding is of questionable significance.

In patients with pauciarticular onset JCA with uveitis there was no apparent difference in the occurrence of either antibodies to histone or anticardiolipin antibodies between those with active or inactive uveitis at the time of serum 
sampling. Four of 11 children with active uveitis were positive for antibodies to histone compared with none of six with inactive uveitis $(p=0 \cdot 2)$, and three of nine children with active uveitis were positive for anticardiolipin antibodies compared with three of six with inactive uveitis $(p=0.6)$.

As children with pauciarticular onset JCA may be a heterogeneous group with children who are older at onset having disease similar to a spondyloarthropathy, we analysed the data separately for the 35 children aged five years or less at disease onset and the 10 children aged more than five years at disease onset. Fifteen of the 35 younger onset children were positive for anticardiolipin antibodies; this did not differ significantly from the three children of the eight tested in the older onset group who were positive for anticardiolipin antibodies. Thirteen of the 35 younger patients with pauciarticular onset JCA were positive for antibodies to histone, compared with only one of the 10 older patients; this difference is not statistically significant $(p=0 \cdot 1)$.

IgM rheumatoid factor was found in only 12 children, 11 of whom had polyarticular onset JCA. The occurrence of anticardiolipin antibodies and antibodies to histone did not differ between the 11 rheumatoid factor positive and 11 rheumatoid factor negative children with polyarticular onset JCA. Anticardiolipin antibodies occurred in seven of 11 rheumatoid factor positive and four of nine rheumatoid factor negative patients tested; antibodies to histone occurred in two rheumatoid factor positive and two rheumatoid factor negative children. Fluorescent antinuclear antibodies were present in 10 of the 12 rheumatoid factor positive serum samples.

Table 3 summarises the results of the HLA antigen frequencies in the white patients There was a significant association between HLA-A2 and the presence of antibodies to histone $(p=0.002)$. This association remains significant even after correcting for the number of HLA antigens studied ( $p=0.02)$. HLA-A3 and DR1 occurred more often in patients without antibodies to histone $(p=0.03$ for the two associations without correction). HLA-A2 was found more often in patients with anticardiolipin antibodies $(p=0.05$ without correction) and DR1 was more common in patients without anticardiolipin antibodies $(p=0.03$ without correction). These associations were statistically insignificant after correcting for the number of HLA antigens studied, however. HLA-DR4 occurred in six of 12 rheumatoid factor positive children with polyarticular onset JCA compared with three of nine rheumatoid factor negative children with polyarticular onset JCA (data not shown).

Although there was a statistically significant association between HLA-DR2 and fluorescent antinuclear antibody positivity $(p=0.02)$, this association was lost after correcting for the number of antigens studied. Even if a positive fluorescent antinuclear antibody test was redefined as the presence of antibody at a titre of $1 / 40$, or even $1 / 80$, no association between positivity for fluorescent antinuclear antibodies and HLA antigens was found (data not shown).

\section{Discussion}

This study confirms a limited number of previous studies that report the common occurrence of antibodies to histone ${ }^{7-9}$ and anticardiolipin antibodies ${ }^{5} 6$ in serum samples from children with JCA, and extends these findings to children with JPsA. Although Ostensen $e t$ $a l^{9}$ reported that antibodies to the core histone

Table 2 Relation between antibodies to histone and anticardiolipin antibodies in serum samples from 114 children with juvenile chronic arthritis $(\mathcal{F C A})$

\begin{tabular}{|c|c|c|c|c|}
\hline Diagnosis & $\begin{array}{l}\text { Antibodies to histone } \\
\text { positive and } \\
\text { anticardiolipin } \\
\text { antibodies } \\
\text { positive (\%) }\end{array}$ & $\begin{array}{l}\text { Antibodies to histone } \\
\text { negative and } \\
\text { anticardiolipin } \\
\text { antibodies } \\
\text { negative (\%) }\end{array}$ & $\begin{array}{l}\text { Antibodies to histone } \\
\text { positive and } \\
\text { anticardiolipin } \\
\text { antibodies } \\
\text { negative }(\%)\end{array}$ & $\begin{array}{l}\text { Antibodies to histone } \\
\text { negative and } \\
\text { anticardiolipin } \\
\text { antibodies } \\
\text { positive (\%) }\end{array}$ \\
\hline $\begin{array}{l}\text { Pauciarticular onset JCA }(n=42) \\
\text { Uveitis positive }(n=19) \\
\text { Uveitis negative }(n=23) \\
\text { Polyarticular onset JCA }(n=20) \\
\text { Systemic onset JCA }(n=12) \\
\text { JPsA }(n=34) \\
\text { Uveitis positive }(n=7) \\
\text { Uveitis negative }(n=27)\end{array}$ & $\begin{array}{ll}7 & (17) \\
2 & (11) \\
5 & (22) \\
3 & (15) \\
0 & (0) \\
2 & (6) \\
2 & (29) \\
0 & (0)\end{array}$ & $\begin{aligned} 18 & (43) \\
10 & (53) \\
8 & (35) \\
8 & (40) \\
8 & (67) \\
23 & (68) \\
2 & (29) \\
21 & (78)\end{aligned}$ & $\begin{array}{ll}6 & (14) \\
2 & (11) \\
4 & (17) \\
1 & (5) \\
0 & (0) \\
2 & (6) \\
1 & (14) \\
1 & (4)\end{array}$ & $\begin{aligned} 11 & (26) \\
5 & (26) \\
6 & (26) \\
8 & (40) \\
4 & (33) \\
7 & (21) \\
2 & (29) \\
5 & (19)\end{aligned}$ \\
\hline
\end{tabular}

Table 3 Relation of antibodies to histone and anticardiolipin antibodies to selected HLA antigens in 83 white children with chronic arthritis

\begin{tabular}{|c|c|c|c|c|c|c|}
\hline HLA antigens & $\begin{array}{l}\text { Antibodies to } \\
\text { histone positive } \\
(n=18)\end{array}$ & $\begin{array}{l}\text { Antibodies to } \\
\text { histone negative } \\
(n=65)\end{array}$ & p Value & $\begin{array}{l}\text { Anticardiolipin } \\
\text { antibodies positive } \\
(n=29)\end{array}$ & $\begin{array}{l}\text { Anticardiolipin } \\
\text { antibodies negative } \\
(n=49)\end{array}$ & p Value : \\
\hline $\begin{array}{l}\text { A2 } \\
\text { A3 } \\
\text { A24 } \\
\text { B7 } \\
\text { B18 } \\
\text { B27 } \\
\text { DR1 } \\
\text { DR5 } \\
\text { DR8 }\end{array}$ & $\begin{array}{r}17 \\
1 \\
5 \\
1 \\
4 \\
1 \\
0 \\
7 \\
5\end{array}$ & $\begin{array}{r}36 \\
21 \\
10 \\
11 \\
9 \\
10 \\
14 \\
13 \\
12\end{array}$ & $\begin{array}{l}0 \cdot 002 \\
0 \cdot 03 \\
\text { NS } \\
\text { NS } \\
\text { NS } \\
\text { NS } \\
0 \cdot 03 \\
\text { NS } \\
\text { NS }\end{array}$ & $\begin{array}{r}23 \\
4 \\
9 \\
4 \\
8 \\
4 \\
1 \\
11 \\
7\end{array}$ & $\begin{array}{r}28 \\
16 \\
6 \\
6 \\
5 \\
7 \\
11 \\
9 \\
10\end{array}$ & $\begin{array}{l}0 \cdot 05 \\
\text { NS } \\
\text { NS } \\
\text { NS } \\
\text { NS } \\
\text { NS } \\
0 \cdot 03 \\
\text { NS } \\
\text { NS }\end{array}$ \\
\hline
\end{tabular}

${ }^{*} \mathrm{NS}=$ not significant $(\mathrm{p}>0.05)$; $\mathrm{p}$ values not corrected for number of antigens studied 
H3 were increased in children with JCA and uveitis, this has not been shown by Pauls et $a l,{ }^{8}$ or ourselves. ${ }^{7}$ In this study only two of the seven patients with JPsA and uveitis were positive for core histones (data not shown). Leak et al have suggested that anticardiolipin antibodies in children with arthritis are correlated with active disease or the presence of superimposed infection in patients with systemic onset JCA. ${ }^{5}$ Caporali et al, however, found no correlation with anticardiolipin antibodies and the erythrocyte sedimentation rate or disease activity. ${ }^{6}$ They also found no association between the presence of anticardiolipin antibodies in children with JCA and either abnormal clotting tests or clinical evidence of thrombotic disease. None of our patients with anticardiolipin antibodies have had thrombotic episodes; we did not assess arthritis activity at the time the serum samples were obtained.

This appears to be the first study analysing serum samples of these patients for the simultaneous presence or absence of the two antibodies. Only a few patients $(11 \%)$ were positive for both antibodies to histone and anticardiolipin antibodies. Although our data show a statistically significantly increased occurrence of the two antibodies together in patients with JPsA and uveitis than in patients with JPsA without uveitis, only a minority of the patients with JPsA and uveitis are positive for the two antibodies. There is no association between the presence of the two antibodies and uveitis in the children with pauciarticular onset JCA. The fact that either antibody alone occurs in $0-55 \%$ of any patient disease group, and that the two antibodies occur together in 0 to about $30 \%$ of the groups suggests that there is a significant heterogeneity among patients, both between, and within, disease groups. The lack of cosegregation of antibodies to histone and anticardiolipin antibodies does not favour the concept that autoantibody production in JCA or JPsA is due only to polyclonal activation.

This study shows a significant association between antibodies to histone and HLA-A2; however, this finding may simply reflect the known association between HLA-A2 and pauciarticular onset $\mathrm{JCA},{ }^{17}$ as it is in this group of patients that antibodies to histone are found most often. No other associations remain between antibodies to histone or anticardiolipin antibodies and any particular HLA antigen once correction is made for the number of antigens studied.

Although many studies have investigated HLA associations with JCA, few have commented specifically on the association between antinuclear antibodies and HLA. Ansell and Albert ${ }^{17}$ indicated that there was an association between fluorescent antinuclear antibodies and DRw8 of borderline significance. Petty $e t$ al ${ }^{18}$ have shown an association between DR8 and fluorescent antinuclear antibodies, and Ragsdale et $a l^{16}$ have shown an association of fluorescent antinuclear antibodies with DR5 and DR8. As another autoantibody, IgM rheumatoid factor, is associated with DR4 in JCA, ${ }^{4}{ }^{15}$ some HLA associations with anticardiolipin antibodies in JCA might also have been expected.
It should be noted that no attempt has been made in this study to group patients by disease duration or joint disease activity at the time of study and it is possible that these variables may have influenced our findings. Except for a study by Leak et $a l^{28}$ that showed a correlation between titres of fluorescent antinuclear antibodies and the erythrocyte sedimentation rate, active joints and uveitis, however, no association between fluorescent antinuclear antibodies and disease activity has been noted. ${ }^{1}$ In this study no correlation could be found between the activity of the uveitis and either antibodies to histone or anticardiolipin antibodies in the patients with uveitis.

In conclusion, although antibodies to histone and anticardiolipin antibodies are fairly common in serum samples of children with chronic arthritis, they occur together in any individual serum sample only rarely. Their presence does not appear to be associated with uveitis or help in the classification of patient groups. Why some autoantibodies occur in the serum samples of some children with chronic arthritis, and whether or not these antibodies are of pathogenic significance remains intriguingly unknown.

Funded in part by grants from the Arthritis Society of Canada and the Mary Pack Fund. Peter Malleson was an Associate of the Arthritis Society of Canada when this work was performed.

1 Lang B A, Shore A. A review of current concepts on the pathogenesis of juvenile rheumatoid arthritis. $\mathcal{F}$ Rheumatol 1990; 17 (suppl 21): 1-15.

2 Petty R E. HLA B27 and rheumatic diseases of childhood. f Rheumatol 1990; 17 (suppl 26): 7-10.

3 Melin-Aldana H, Giannini E H, Glass D N. Immunogenetics of early onset pauciarticular juvenile rheumatoid arthritis. f Rheumatol 1990; 17 (suppl 26): 2-6.

4 Vehe R K, Begovich A B, Nepom B S. HLA susceptibility genes in rheumatoid factor positive juvenile rheumatord genes in rheumatoid factor positive juvenile rhe
arthritis. $\mathcal{F}$ Rheumatol 1990; 17 (suppl 26): 11-5.

5 Leak A M, Colaco C B, Isenberg D A, Dudeneu C, Ansell B M. Anticardiolipin and anti-ss DNA antibodies in antinuclear positive juvenile chronic arthritis and other antinuclear positive juvenile chronic arthritis and other childhood onset rheumatic disease
Rheumatol 1987; 5 (suppl 2): 18 .

6 Caporali R, Ravelli A, De Gennaro F, Neirotti G, Montecucco C, Martini A. Prevalence of anticardiolipin antibodies in juvenile chronic arthritis. Ann Rheum Dis 1991; 50: $599-601$.

7 Malleson P, Petty R E, Fung M, Candido E P M. Reactivity of antinuclear antibodies with histones and other antigens in juvenile rheumatoid arthritis. Arthritis Rheum 1989; 32 919-23.

8 Pauls J D, Silverman E, Laxer R M, Fritzler M J. Antibodies to histones $\mathrm{H} 1$ and $\mathrm{H} 5$ in sera of patients with juvenile rheumatoid arthritis. Arthritis Rheum 1989; 32: 877-83.

9 Ostensen M, Fredriksen K, Kass E, Rekvig OP. Identification of antihistone antibodies in subsets of juvenile chronic of antihistone antibodies in subsets of juve
arthritis. Ann Rheum Dis 1989; 48: 114-7.

10 Tuaillon N, Muller S, Pasquali J L, Bordigoni P, Youinou P, Van Regenmortel M H. Antibodies from patients with rheumatoid arthritis and juvenile chronic arthritis analyzed with core histone synthetic peptides. Int Arch Allergy Appl Immunol 1990; 91: 297-305.

11 Dobloug J H, Forre O, Kass E, Thorsby E. HLA antigens and rheumatoid arthritis: association between HLA-DRw4 positivity and IgM rheumatoid factor production. Arthritis Rheum 1980; 23: 309-13.

12 Hamilton R G, Harley J B, Bias W B, et al. Two Ro (SS-A) autoantibody responses in systemic lupus erythematosus. Correlation of HLA-DR/DQ specificities with quantitative expresion of Ro (SS-A) autoantibody. Arthritis Rheum 1988; 31: 496-505.

13 Harley J B, Sestak A L, Willis L G, Fu S M, Hansen J A, Reichlin M. A model for disease heterogeneity in systemic lupus erythematosus. Relationships between histocom patibility antigens, autoantibodies, and lymphopenia or renal disease Arthritis Rheum 1989; 32: 826-36.

14 Genth E, Mierau R, Genetzky P, et al. Immunogenetic associations of scleroderma-related antinuclear antibodies. Arthritis Rheum 1990; 33: 657-65.

15 Forre O, Dobloug J H, Hoyeraal H M, Thorsby E. HLA antigens in juvenile arthritis: genetic basis for the different subtypes. Arthritis Rheum 1983; 26: 35-8.

6 Ragsdale C G, Pachman L M, Sullivan D B, Kapur J Rodvany R, Goletz J. Histocompatibility correlates of course and outcome in juvenile arthritis [abstract]. F Rheumatol 1986; 13: 983. 
17 Ansell B M, Albert E D. Juvenile chronic arthritis, pauciarticular type. In: Albert E D, et al, eds. Histoco

18 Petty R E Schroed M-L Malleson P N, Oen K G. HLA DR antigens in pauciarticular onset juvenile rheumatoid DR antigens in pauciarticular onset juvenile
arthritis [abstract]. $\mathcal{F}$ Rheumatol 1986; 13: 983 .

19 Brewer E J, Bass J, Baum J, et al. Current proposed revision of JRA criteria. Arthritis Rheum 1977; 20: 195. 20 Munthe E. Special meeting on nomenclature and classification of

21 Southwood T R, Petty R E, Malleson P N, et al. Psoriatic arthritis in children. Arthritis Rheum 1989; 32: 1007-13.

22 Friou G J. Fluorescence spot test for anti-nuclear antibodies. Arthritis Rheum 1962; 5: 407-10.

23 Lerner M R, Steitz J A. Antibodies to small nuclear RNA complexed with proteins are produced by patients with systemic lupus erythematosus. Proc Natl Acad Sci USA 1979; 76: 5495-9.

24 Laemmli U K. Cleavage of structural proteins during the assembly of the head of bacteriophage T4. Nature 1970 227: $680-5$.

25 Towbin H, Staehelin T, Gordon J. Electrophoretic transfer of proteins from polyacrylamide gels to nitrocellulose sheets: proteins from polyacrylamide gels to nitrocellulose sheets: 1979; 76: 4350-4

26 Candido E P M, Dixon G H. Sites of in vivo acetylation in trout testis histone IV. $\mathcal{F}$ Biol Chem 1971; 246: 3182-8.

27 Terasaki P I, Bernoco D, Park M S, Ozturk G, Iwaki Y. Microdroplet testing for HLA-A, -B, -C, and -D antigens. Am f Clin Pathol 1978; 69: 103-20.

28 Leak A M, Ansell B M, Burman S J. Antinuclear antibody studies in juvenile chronic arthritis. Arch Dis Child 1986; 61: $168-72$. 